\title{
Compassionate leadership? Some reflections on the work and life of Michael Lapsley
}

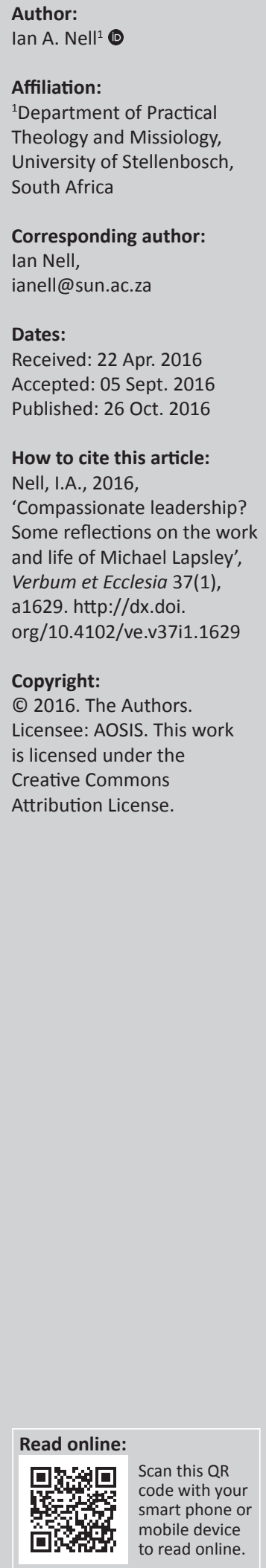

In June 2007, I had the privilege of attending a Healing of Memories workshop lead by Father Michael Lapsley, one of the founder members of the Institute for Healing of Memories. The purpose of the workshop was to help the predominantly white members of a middle class Dutch Reformed congregation in the Northern Suburbs of Cape Town and the predominantly coloured members of a congregation of the Evangelical Lutheran Church in Elsies River on the Cape Flats, to share their stories of the past with regard to apartheid with each other. Apart from the stories that were told and the sharing of experiences about the apartheid history that took place, I was struck by the way in which Father Lapsley conducted the workshop. There was a deep compassion for all the participants as was embodied through the way in which he treated each of us with respect. But apart from his cordiality in leading the workshop, one could sense a deeper source of compassion, a source revealing a compassionate understanding of God's presence amidst the violence and turmoil in our broken world. The aim of this article is to reflect on whether one could speak of something like 'compassionate leadership', and to take a closer look at the relationship between compassion and God images in the life and work of Michael Lapsley. Special attention will be given to the way in which he exercises leadership through his many involvements related to his own personal story of trauma.

Intradisciplinary and/or interdisciplinary implications: This article presents literary research on the notion of compassionate leadership as a specific kind of leadership. The results indicate that the leadership of Father Michael Lapsley does indeed portray features of this kind of leadership. The research can become the source for finding new strategies for religious leadership.

So towards the end of the interview, Father Lapsley shared this final quote which exemplifies that his heart is full of hope and compassion for those who attend his Healing of Memories Institute: 'The glory of God is a human being fully alive'. (Vernikof 2013:n.p.)

\section{Introduction}

In June 2007, I attended my first 'Healing of Memories workshop'. The workshop was the result of a relationship that developed over a number of years between two congregations. Eureka Congregation from the Evangelical Lutheran Church in Elsies River, Cape Town, and Sonstraal Congregation of the Dutch Reformed Church in Durbanville. The initial purpose of the combined project of the two congregations developed from the desire to cross cultural and denominational boundaries and to get to know the living conditions and traditions of one another. The original impetus had a dual origin. From the side of the Eureka congregation, there was the involvement of Hans Engdahl ${ }^{1}$ (who was a member of Eureka congregation) and his friend Deon Snyman. ${ }^{2}$ They were interested in seeing what could develop through this kind of relationship in terms of reconciliation, healing and restitution in a post-apartheid South Africa. From the side of the Sonstraal congregation, there was the desire, because of their participation in the processes of the South African Partnership for Missional Churches (SAPMC), to become involved in a community from a different cultural and denominational context.

For more than 2 years, a group of people from each of the congregations came together every month. The meetings alternated between the two buildings of each congregation, and from time to time they also attended one another's Sunday morning services. With a hospitable relationship 
that developed between the two groups they decided to make use of the help of the Institute for Healing of Memories (IHOM). The purpose was to give the members of each congregation the opportunity to tell their stories and experiences of apartheid from 'different sides of the railroad'. Because of the good relationship that existed between Deon Snyman and Father Michael Lapsley, it was possible for Father Lapsley to be personally involved in the workshop as the main facilitator. ${ }^{3}$ The workshop took place in an island setting during the weekend of 01-03 June 2007, and was attended by 25 people with an equal number of participants from both congregations. In the meantime, I had the privilege of being involved in a number of these workshops, because the IHOM workshops ${ }^{4}$ became part of the Master of Divinity programme offered at the Faculty of Theology at Stellenbosch University.

It was, however, during the first workshop that I became aware of the particular way in which Father Lapsley exercised his leadership (see Figure 1, an image of Father Lapsley). His style and approach was totally different from what one normally finds in the leadership literature by prominent scholars in the field. ${ }^{5}$ Reflecting on my experience back then, I think what captured my attention was his physically embodied vulnerability, the long periods of silence between his sentences and the soft voice with which he addressed his audience and his style of leadership that one can describe as 'compassionate leadership', which will be the main focus of this article. This brings me to the central research question: Can one speak of 'compassionate leadership' in the life and work of Father Lapsley, and if so, is it possible to relate this kind of leadership to some underlying 'compassionate Godimages'?

To answer the research question, I want to address the argument in the following ways: Firstly, I want to give

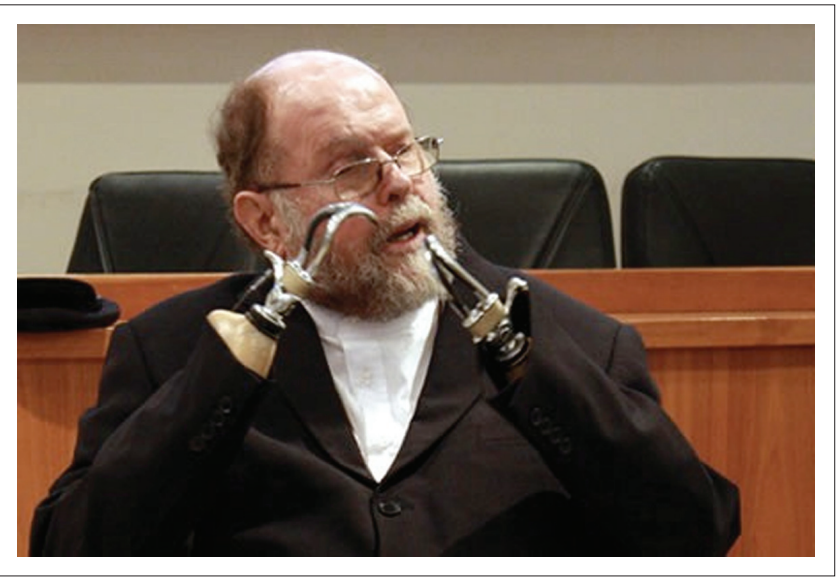

Source: Father Michael Lapsley, 2012, viewed 12 March 2015, from https://www.aur.edu/ wp-content/uploads/2012/04/csmri-father-lapsley.jpg

FIGURE 1: Father Michael Lapsley.

3.For more information on the Institute for Healing of Memories, visit: http://www. healingofmemories.co.za

4.'Put very simply, a Healing of Memories workshop is at heart a weekend-long journey that moves from pain to hope' (Lapsley \& Karakashian 2013:147).

5.Cf. Haslam, Reicher and Platow (2011), The New Psychology of Leadership. The authors start their book with a discussion of the so-called great man theory in leadership concentrating on the 'charisma' and 'character' of the leader. attention to some theoretical perspectives on the concept of 'compassion', and then use these as heuristic lenses to look at Father Lapsley's style of leadership. Secondly, I will spend some time giving a short biographical account of his life story before moving on to analyse his style of leadership while acting as a facilitator during a Healing of Memories workshop. Lastly, I want to probe into some underlying God images that might influence his style of leadership before drawing some final conclusions in answering the research question.

\section{Theoretical perspectives}

The purpose of this section is to examine some literature on leadership to see whether one can find a relation between leadership and compassion, and if so, what the link between these concepts might be. Firstly, I want to search through secular literature on leadership to see whether one finds the concept of compassion, before moving on to look at some perspectives from psychology, education, religion and pastoral care. The different perspectives will hopefully help to act as heuristic devices when I probe into the leadership style of Father Lapsley in trying to take a deeper look at possible underlying God images that influenced his style of leadership.

\section{Leadership theory perspectives}

George (2003) developed the so-called Authentic Action Wheel in which he describes five characteristics of what he calls authentic leadership. In a very practical way, he describes the essential qualities of an authentic leader. He goes on to explain the ways in which leaders can develop these qualities in their individual lives en route to authentic leadership. Based on 30 years of empirical research he comes to the conclusion that authentic leaders do have a sincere desire to serve other people; that they know themselves quite well and that they normally do fine to lead others from some key values that they yearn for. According to him, authentic leaders demonstrate the following five characteristics: (1) they understand their purpose, (2) they do have some strong values on doing the right thing, (3) they establish reliable relations with the other, (4) they do have a strong selfdiscipline and act on their core values and (5) they are passionate about their mission. He goes on to attach to each of the five dimensions (purpose, values, relationships, selfdiscipline and the heart) a specific characteristic (see Figure 2).

George (2003:40) discusses the five dimensions of authentic leadership and the characteristic that relates to each of them. It is very interesting that he uses the word 'heart' as a dimension and that he connects it with the characteristic of compassion. In this regard, he writes that compassion can be understood as being sensitive to the circumstances of another person, to be open to other people, and to be willing to help and support another person. According to him, it becomes evident that when one develops compassion, he or she also learns to be authentic.

For the purpose of this research he discusses an important aspect of compassion as part of leadership when he writes 


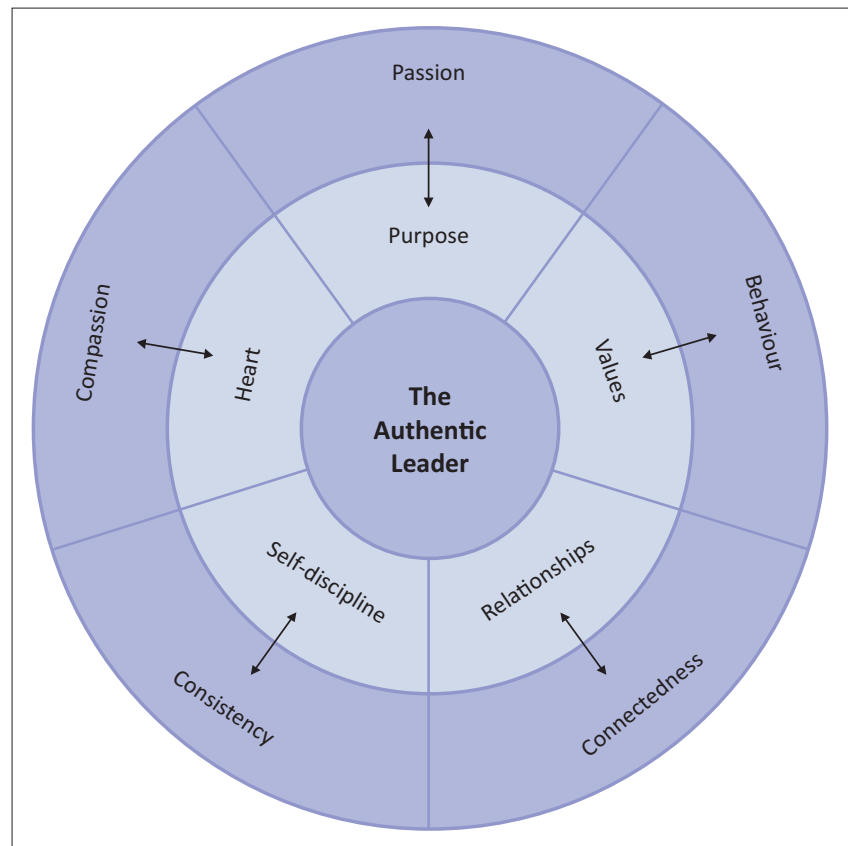

Source: George, B., 2003, Authentic leadership: Rediscovering the secrets to creating lasting value, Wiley, Hoboken, NJ

FIGURE 2: Authentic action wheel.

about the way that leadership can develop compassion. He is of the opinion that compassion develops when leadership makes the effort to get to a better understanding of the life narratives of people, participates in community projects, gets involved in groups from other race and ethnic groups and undertakes trips to developing countries. One must remember, he is writing from a white American perspective, but it is especially his insights concerning 'learning from people's narratives' and 'involvement with people from other race and ethnic groups' that can help as important heuristic devices for further probing into 'compassionate leadership'.

\section{Psychological perspectives}

In looking at psychological perspectives, Parkyn (1995:244) points to the fact that in everyday use compassion normally has two meanings: Firstly, it relates to emotions that people experience when they come in contact with the pain and suffering of other people. Secondly, it recounts the purposeful decision to move into the position of the person experiencing suffering with the drive to do something about their suffering. He goes on to conceptualise compassion and writes that the concept includes a desire to do something about the suffering of a fellow human being but also an act that is necessary to make it happen. According to Parkyn (1995:244), the desire is, from a Christian-ethical perspective, not a sufficient response to the suffering of another person. Compassion ought to find an active involvement with the destitute person from the side of the one showing compassion.

\section{Educational perspectives}

In a very discerning article, the Stellenbosch educationist Yusef Waghid (2004:526) shows in a convincing manner that the way in which the teaching of university students, concerning citizenship in South Africa since the first democratic elections in 1994, has been inspired by liberal and communitarian concepts. According to him, it was specifically the discourses concerning policy directions on 'values, education and democracy', where the liberal and communitarian values regarding citizenship were influential. Although he does have a lot of appreciation for these concepts of citizenship education, he is, however, of the opinion that in itself they are not enough to enhance the necessary educational transformation of institutions.

According to Waghid (2004:534-535), the liberalcommunitarian concepts of citizenship do have limited potential to bring about meaningful transformation in the educational institutions of South Africa and must be supplemented and strengthened by 'compassion'. He is of the opinion that values like social justice, equality and Ubuntu can help much more with the moral outcomes necessary to become a 'good citizen'. He writes that educational transformation can be helped by the concept of compassion to cultivate in learners the capacity for nationbuilding and that there is more to nation-building than only equipping them with practical-reasoning skills in critical judgement and rationale and inter-subjective discussion. $\mathrm{He}$ states it in the following way:

Nation-building in South Africa also requires that pupils be taught to have respect for human suffering and to take the suffering of others seriously, particularly since the majority of South Africans have been subjected to decades of racial discrimination and political exclusion. It is here that the current liberal-communitarian citizenship education agenda in South Africa remains incomplete as an enabling mechanism for substantive transformation ... Whereas the South African program outlined above highlights the importance of teaching pupils to become democratic, socially just, equitable, egalitarian, non-racist and non-sexist, dignified, open, accountable, respectful, reconciliatory and law-abiding, it does not specifically mention the necessity for pupils to become trustworthy, generous and compassionate - values which focus greater attention on those who suffer and are oppressed and give less attention to pupils' self-interests. (Waghid 2004:535)

From the quotation above it is obvious that Waghid appeals that compassion ought to be an important part of the values for citizenship education because it sensitises learners about the suffering of fellow human beings that took on specific forms because of South Africa's history. Another important contribution by focussing on compassion is that it helps the learners not only to focus on their individual self-interest, which is a characteristic of liberal-communitarian values, but also to become aware of the suffering and needs of others around them. These insights highlighted by the analysis of compassionate leadership speak for itself.

\section{Religious perspectives}

The practical theologian Ruard Ganzevoort (2013:17) refers to the work of Karen Armstrong who is of the opinion that the concept of compassion can be found in the essence 
of most religious traditions. He gives a summary of her thoughts: Compassion starts with the realisation of the fundamental connectedness with everything and everybody. Human beings form part of the world and your choices do have an influence on other people, just like the choices of others do have an influence on you. The second aspect concerns the willingness of each one of us to allow another person to touch you in the sense of feeling with, in other words to have 'com-passio'. The third step is the question whether one is prepared to accept responsibility for the other person. Connectedness, to be touched by another and to accept responsibility, makes up compassion and provides an additional important lens that one can use in analysing compassionate leadership.

\section{Pastoral perspectives}

Looking at some pastoral perspectives, Louw (2008:14) points to the fact that compassion is one of the deepest human needs. The word is a combination of two Latin words, namely patior and cum, and can literally be translated 'to suffer with'. According to Thesnaar (2010:270), this requires from the person involved in pastoral work not only to understand the suffering of another person but also to allow oneself to suffer with the other person by standing next to them. Van der Ven et al. (2003:57) correctly shows that compassion is not something that comes naturally to all, it is something that needs to be learned.

In this regard, Johnson (1987:35) is of the opinion that empathy, the capacity to identify with the feelings of another person and through that to understand their frame of reference, is an important part of compassion. It means that one has to develop the capacity to step into the shoes of the other and to see the world from their perspective. Compassion normally takes place in community, where people support each other and through that develop freedom for the other. These perspectives overlap to some degree with the psychological perspectives but what gives the pastoral perspective a unique angle is the way in which they are motivated by biblical-theological notions of compassion. The attention now turns to these.

\section{Biblical-theological perspectives}

Starting with Genesis, one discovers that the concept of compassion is a truly biblical notion. Although the Hebrew word for compassion is translated as love and grace, it is deeply rooted in God's covenant with his people (Thesnaar 2010:271). The covenant evolves from a very specific relationship between God and his people and as the narrative develops God's compassion for Israel becomes more visible. Reading the Old Testament through this lens, one finds the concept of compassion in almost every narrative; it is continuously and constantly present. The narrative of this compassion between God and his people continues in the New Testament. God's covenant attains new meaning when the main character of the covenant appears as the main character on the stage. Jesus' ministry to the marginalised and sick serves as a strong witness to his compassion with people in need. In this regard, the public ministry and life of Jesus of Nazareth is a unique model of God's compassion with people. This can be particularly observed when one reads Matthew 9:36: 'When he saw the crowds, he had compassion on them, because they were harassed and helpless, like sheep without a shepherd'.

According to Louw (2008:441), the literal sense of this text relates to the sickening of the intestines. The paraphrasing of the Greek word that one finds in this passage shows that his intestines started to move after seeing the needs of the people. $\mathrm{He}$ is of the opinion that this is a clear sign of the compassion Jesus had with people and that one cannot interpret the event without reflecting on what happened on the cross, because it was on the cross that the compassion of a suffering God was revealed. Louw (2008) concludes:

Compassion indicates sensitivity. It describes the virtue of unconditional love and the willingness to become involved. Part and parcel of compassion is empathy, the capacity to enter, understand and respond to another's frame of reference. (p. 281)

In this regard, 'space' becomes another important concept to keep in mind when reflecting on compassion because one cannot limit one's reflection only to personal and pastoral spaces. According to Thesnaar (2010), it is possible to make space for compassion in the ministry on different levels and in different places:

It could be in the liturgy in a Sunday service where people in need for healing can experience the therapeutic value of the Holy Communion. Serving Holy Communion is a therapeutic event, which provides comfort in the midst of disruption and crisis. (p. 272)

It can also be at other times and in different places where people of faith are busy with liturgical, kerygmatic, koinonial and diaconical activities.

The different perspectives reflected on in this section all contribute in some way or another to developing multifocal lenses that one can use to see whether it is possible to speak about compassionate leadership when analysing the leadership style of Father Lapsley. Before undertaking the analysis it will help to give a short biography of his life that can serve as a helpful background before probing deeper into the topic of compassionate leadership.

\section{A short biography of Father Michael Lapsley}

Father Lapsley was born in New Zealand and as a young priest received the instruction to go and minister in South Africa as part of his belonging to a religious order. This was in 1973 and during the high tide of apartheid. He was an activist from his earliest days and did not hesitate to become involved in the freedom struggle. He was banned from South Africa to Lesotho for some years and later moved to Zimbabwe because he literally became a 'thorn in the flesh' of the apartheid government. This was also the backdrop to 
the bomb that exploded in his face on 28 April 1990 after opening a parcel that came from South Africa, leaving him without hands, an eye and hearing loss in one ear. The explosion did not kill him, and after a long time of recuperating in Australia he returned to South Africa. Upon his return, he soon realised that many were left with scars from apartheid, and with a story to tell. It was against this background that he decided not to give up hope but rather to become a wounded healer. Thus, in 1998 he founded the IHOM to help people with the process of healing through his workshops. This is a remarkable story of courage from a freedom fighter to a wounded healer with a message of hope to the whole world.

The book containing his memoirs that he wrote with Stephen Karakashian consists of three sections. In his own words he describes these in the following way (Lapsley \& Karakashian 2013):

Part I recounts the pivotal event of my life, the bombing that took away my hands and eye. It then continues through my long convalescence and adjustment to my disability.

Part II tells the story of my life as a freedom fighter. But first it circles back to my childhood growing up in New Zealand and the development of the religious faith that has shaped every aspect of my existence. I then recount the shock of my encounter with apartheid South Africa and how my faith was shaken by the experience, my banishment from South Africa, and the years as a freedom fighter in Lesotho and then Zimbabwe.

Part III briefly revisits the bombing, and then describes how my life changed as I moved from being a freedom fighter to becoming a healer and eventually founding the Institute for Healing of Memories.

The remainder of the memoir, Part IV, focuses on the Institute's work worldwide, first in South Africa and later reaching across the globe for those who are in need of help and healing. (p. x)

From this short summary, the focus of the research starts to crystallise and centres on the notions of compassion, leadership and the role of faith. In the next section, attention will shift specifically to see whether one can find aspects of compassionate leadership in the life of Father Lapsley. In this regard, I thought it might be helpful to first concentrate on the way that a Healing of Memories workshop is conducted and the way he participates as a facilitator. Therefore, I want to give a short description of the different components of the workshop before concentrating on the four aspects of compassionate leadership that starts to evolve from the reflection. There are two reasons for this approach: on the one side, because it relates to the fact that Father Lapsley facilitated hundreds of these workshops, not only in South Africa but also all around the world, influencing the lives of many people; on the other side, because it was at such a workshop where I experienced his style of leadership first-hand. In this regard, the research makes use of what in methodological literature is referred to as Participatory Action Research. ${ }^{6}$

\section{Compassionate leadership through Healing of Memories}

In a previous research project that I did on the method of a Healing of Memories workshop (Nell 2011) it became clear that the following components or acts $^{7}$ form part of the workshop ${ }^{8}$.

\section{A real life drama}

Taking place over a weekend in an 'island setting', this workshop by the IHOM is conducted by a number of trained facilitators, headed by a coordinating facilitator. After the welcoming session, the participants are asked to write their expectations down, which is then posted on a wall. Following this, they are introduced to the 'Mina Nawe', 9 a group of seven amateur dramatists and Xhosa-speaking women from Khayelitsha, who through performing this drama take one back to the life and circumstances of South Africa in the mid1980s, in a 'state of emergency'. The Security Police, keeping law and order in the townships, are heavily armed with armoured vehicles and automatic rifles, firing on protesters creating havoc. A young girl who is shot in front of her mother, is ensued by communal weeping from the loss of life. The actors move in and out of the circle, making use of songs, dialogue and interaction with the audience, incorporating them into the drama. At the end, the main character summarises the reasons for the existence of the group and gives her personal motivation for her participation.

\section{Conversations in the big group}

After watching the drama, the group is to reflect on the feelings they experienced during the drama. The evening ends with questions, such as: Could you identify with the pain and loss of the characters? What emotions did you experience while watching the drama group? What in the act can you use when you reflect on your own history? What influence did these events have in your life story?

\section{Creative exercise and narrative}

The following morning, in an hour long creative exercise, participants are asked to make a drawing of their 'river of life' on a large piece of paper, using colouring crayons. They can draw whatever they like, whether an experience of joy or sorrow, pain or exclusion, as long as no words are used. The purpose of the exercise is to tap into the right, or creative side of the brain, by drawing pictures rather than the use of verbal descriptions of their life stories, and to give expression to feelings and emotions through art as part of the 'healing process'. The large group is then divided into smaller subgroups of five, with each assigned a facilitator. Content of

7.The different elements of the workshop are a summary of the section dealing with the workshop from the article referred to in footnote 11.

8.For an account of Lapsley's own description of a workshop, see Lapsley and Karakashian (2013:193-205).

9.'The name of the group, Mina Nawe, means "me and you" in Zulu, and this reflects our philosophy that healing comes from a caring and compassionate connection between people' (Lapsley 2013:146). 
these sessions remain confidential. For the rest of the day, each participant is allocated $45 \mathrm{~min}$ to tell their story and to explain their drawing, without interruption. Afterwards, time is given for reflection and questions.

\section{Festivity and liturgy}

Finally, for 'breathing space', two related activities follow. After a tough day of dealing with pain and sorrow from the past, an informal social gathering is arranged for the evening, comprised of festivity, light-heartedness, music, wine and food. The following morning, a 'public ritual' in the form of a participatory liturgy under the guidance of the coordinating facilitator is planned. The whole group decides on the central theme of the liturgy and everyone contributes in one way or another.

From the different activities just described and keeping the heuristic lenses developed in paragraph 2 in mind, I want to summarise Lapsley's 'compassionate leadership' by making use of the following four headings with a short reflection on each.

\section{Creating space}

One of the things that caught my attention during the workshop was the way in which Father Lapsley managed to create different spaces. ${ }^{10}$ The workshop started with the physical space of the participants sitting in a circle. From that moment onwards, he time and again created and invited them into safe spaces for experiencing, sharing, thinking and reflecting. This process continued through the spaces that he opened up for creativity to draw one's river of life, to tell their story in a small group, to celebrate life and to participate in the liturgy at the end of the workshop.

In light of the different perspectives on compassion as discussed in paragraph 2 above, compassionate leadership comes to the fore in the way that Father Lapsley in a compassionate way helped the participants to move into different spaces and to feel safe and not coerced. Linking this activity with the lenses of compassion one can speak about 'compassionate spaces'. By listening attentively to the participants' stories of pain and suffering, it created the opportunity to look at life from another person's perspective. The spaces for creativity (drawing and shaping clay symbols) provided an appropriate setting to allow difficulties coming from the heart to surface.

\section{Cultivating imagination}

The next activity that inspired me was the way in which Father Lapsley cultivated the imagination of the participants. From the opening scene of the drama, through the symbolic representation of life stories by way of drawing one's 'river of life' and telling the story to the participants in the liturgy at the end, the imagination of the participants was in different ways at work. Maybe the most imaginative of all these activities was Father Lapsley's own physical condition that was a testimony to vulnerability and healed wounds. The fact that he experienced severe physical pain and suffering in his own body gave imaginative credibility before a word was even spoken.

In the light of the different theoretical perspectives on compassion it looks as though a lively imagination is a precondition for compassionate leadership. The fact that Christian leaders have a rich source of documents in terms of the Scriptures and tradition to work with, provides a wonderful foundation for cultivating imagination. Not many of us carry the physical wounds of suffering in such a visible way in our bodies, but most of us are deeply aware of our own vulnerability. In the words of Henry Nouwen (1972), most of us are 'wounded healers' opening up the possibility to work imaginatively through our wounds towards healing. In a recent paper by Francis Nyamnjoh, a professor in Anthropology at the University of Cape Town with the interesting title: Incompleteness: Frontier Africa and the Currency of Conviviality, he discusses how the dominant discourses in society are permeated by 'completeness' leaving little room for 'incompleteness', and thus for compassion. ${ }^{11}$

\section{Crafting community}

Lesslie Newbigin writes, 'Jesus didn't come to write a book but to form a community'. Linked to the experience of Father Lapsley creating different spaces I also appreciate the way in which he managed to craft a community. He does have a unique ability to create the feeling that you are not alone on the journey to healing. One of the first activities we participated in the big group was to listen to the expectations each participant shared concerning the workshop and to share them with each other. The thought that in a special way supports the importance of crafting a community is where Father Lapsley (2013:194) refers to the words of Donald Shriver: 'Some say', Laugh and the world laughs with you; cry, and you cry alone. 'I think it's precisely the opposite. Laughter can separate us; pain unites us. It's what in one way or another we all understand'. It sounds as though shared pain and suffering do indeed craft community.

The words of Shriver, quoted by Father Lapsley, once again emphasise the way in which compassion is also underlying the crafting of community. When suffering and tears are shared, compassion develops with the story and situation of the other person. In the pastoral perspectives we saw how important it is not only to understand the suffering of another person but also to allow oneself to suffer with the person who is on the receiving end. It was also mentioned that it is not something that comes naturally, it must be learned. Part of the learning process is likewise the role that empathy plays in the sense of feeling with the other and sharing the person's frame of reference, all activities that craft community.

11.The STIAS Lecture took place on 14 April 2015 in the JC de Wet lecture hall, at Stellenbosch University. Professor Francis Nyamnjoh presented a talk with the title: Incompleteness: Frontier Africa and the Currency of Conviviality. 


\section{Creative liturgy}

Shaping a creative and participating liturgy is in a certain sense the culmination of what has thus far been discussed about compassion. All the elements of the liturgy are planned by the whole group within a spirit of compassion. From the choice of hymns to be sung, to the sharing of communion, all are working with the underlying assumption and consciousness of brokenness and compassion with the suffering of others. The peace symbol that the participants had to shape from clay and explained to the group serve as imaginative symbol that compassion is filled with hope and opens a future perspective. Father Lapsley (2013:143) reflects on the importance of liturgy in the following way: 'I had long been interested in the power of creative liturgy as means of enacting our human journey'.

In discussing the biblical-theological perspectives the important role of Holy Communion was referred to. It once again reminds one of what is called the 'wholeness of brokenness', and is important to take into account when reflecting on leadership (Meyer 2000). The taking, breaking and sharing of the bread and drinking from the cup proves imaginative possibilities for reflecting on leadership.

\section{Compassionate leadership}

Looking at the four leadership activities of Father Lapsley in the previous section, namely, creating space, cultivating imagination, crafting community and constructing liturgy, it becomes clear that one can indeed speak about compassionate leadership. If one compares these concepts to the following definition of leadership one can see some interesting correlations:

Leadership involves a person, group or organisation who shows the way in an area of life - whether in short- or long term - and in doing so both influences and empowers enough people to bring about change in that area. (Banks \& Ledbetter 2004:16)

The four ' $c$ 's are all activities showing the way through influence by empowering people to change. But, it seems as though the adjective 'compassionate' does indeed add a specific quality to this understanding of leadership. It is in quest of this qualitative difference of compassionate leadership in the life of Father Lapsley, that the attention shifts to some underlying God images at play in his work and ministry.

\section{Compassionate God images}

In the introduction to Redeeming the Past, Father Lapsley reflects on faith as what he calls 'the central and unifying strand of my life'. He writes (Lapsley 2013):

In a sense, this memoir is the story of my call to live out my faith as part of the liberation of all Gods' people. While not everyone is religious, all of us are spiritual beings in that we seek to understand and find meaning in our lives. For most people, as for me, this is a lifelong quest and not necessarily an easy one. Not wishing to trumpet my religious faith, I have tried instead to let my actions bear it witness. My own faith journey encompassed piety of an adolescent, a crisis engendered by the conflict between pacifism and the armed struggle, long patient years in the liberation movement, recuperation from a bomb that nearly killed me, and finally a more mature healing faith that, while firmly rooted in the Christian tradition, embraces the full range of human spiritual experience. (p. xi-xii)

Reflecting on what Father Lapsley calls 'the full range of human spiritual experience' and after reading his book, one finds what one can call 'evolving God-images'. It is obvious from his narrative that he grew up in a pious family and his references to God images during his childhood days point in the direction of a loving and compassionate God. He speaks about a 'home-grown faith' (Lapsley 2013:39) and then tells that he was from his earliest years very religious and devout. He was, during his childhood years, involved in two churches as an 'altar server'. It was especially the rituals, confessions and discipline that kindled his faith.

At the young age of 22, he became a Professed Member of the Society of the Sacred Mission (SSM) ${ }^{12}$ and was also ordained by them. In this regard, he writes: 'Joining an order was my way of obeying the radical demands of following Christ and taking the gospel to its logical conclusion'. At the age of 24, he was ordained as a priest and enjoyed working in his first parish. He writes (Lapsley 2013:52): 'I adored the parishioners and they adored me. I really blossomed in every way. I loved the pastoral work and was extremely well received by the congregation'. One finds in these remarks the traces of a person that understood from a tender age something about God's compassion for people.

A new phase in his journey of faith started in 1976 after he moved to Lesotho because the South African government did not want to extend his visa to stay in the country. It was during this time that he experienced 'a crisis of faith'. Up to this stage he was a staunch supporter of pacifism but realised that it did not really change the circumstances of black people. He writes (Lapsley 2013):

So I began to read scripture not just with the eyes of what I had been taught in church but from the perspective of someone committed to the liberation of all people. (p. 73)

In the heart of this struggle he also saw the heart of the gospel, namely to be willing to offer your life for the freedom of others. Underlying this approach, one discovers a developing God image that Father Lapsley (2013) describes in the following way:

I suddenly came face to face with a God who always takes the side of the poor and oppressed. I was seized by the fervent belief that, within our context, the liberation movement was the human embodiment of the gospel message of love and justice. (p. 78)

According to Father Lapsley (2013:95), even his own Anglican colleagues were uneasy with his views at that time. In this God image, one sees an image of God's compassion in the way that God sides with the poor and the oppressed.

12.St Michael House, close to Canberra, was the headquarters of the Society of the Sacred Mission (SSM). 
The next phase in Father Lapsley's faith journey commenced after he moved to Zimbabwe. Initially, he served in a parish but later became head of a programme known as 'Development of Theology' and started to work for the 'Lutheran World Federation' (LWF). In this regard, he writes the following (Lapsley 2013:113): 'My understanding of God, faith and belief went through its own evolution during the time I worked for the Lutheran World Federation'. He goes on to tell that the way in which he grew up and the way that his Anglican background shaped him, many times had a narrow view of God and the church. Through his work at the LWF, he not only came in contact with a rich diversity of churches and denominations but he also met people from other faiths that were united by the struggle. He had to learn to give expression to his faith in ways that would not offend other people and this caused a reformation of his spirituality. He writes (Lapsley 2013):

The scriptural imperatives of social justice took on increasingly urgency for me, and more and more I saw a God who welcomes all members of the human family. So my faith developed, not so much from reading books as from working in the trenches and living with danger. (p. 113)

In the way that God welcomed everybody in the human family we once again discover another side of God's compassion.

The bomb explosion on the 28th of April 1990 (25 years ago) not only had a huge impact on Father Lapsley's life but also presented a new side of God's face. He writes (Lapsley 2013):

Alone in the emptiness, I felt the presence of God surrounding me and I knew that Mary, who had watched her Son being crucified, understood what I was going through ... God accompanied me through the harrowing hours that lay ahead as the medical staff worked to save my life and minimise the damage to my body. (p. 2)

During his time recovering after the bombing he writes: 'In those darker moments I relied on my simple childhood faith in a loving God and in Jesus who suffered like me and was crucified' (Lapsley 2013:11). It is obvious that the image of a 'wounded and suffering God', full of compassion, was an important God image during this painful time in his life.

Wounds need healing and once again a new God image started to evolve in Father Lapsley's life and work after returning to South Africa in 1991. It was specifically after he founded the IHOM in 1998 that the image of God as a 'wounded healer' became prominent. In his own words (Lapsley 2013:205):

While a Healing of Memories workshop does not depend on Christian imagery, there are echoes of the gospel that are implicit in its design. The heart of the gospel story is that Jesus triumphs over crucifixion and death, and Thomas, overcoming disbelief, thrust his hands into the still-visible wound of the resurrected Jesus. So like Jesus, our wounds may remain visible but they can be healed, and then we are no longer their prisoner. The signs of the crucifixion had not disappeared, but Jesus' wounds were no longer bleeding. I think that tells us something about God's will for the human family - which we are called to recognise and acknowledge the terrible things that we have done to each other, but then we are called to stop being crucifiers. We are called not to be a Good Friday people, but to be an Easter Day people. The idea of the wounded healer is thus deep within Christian theology. The victim triumphs not by becoming a victimiser of others, but rather by becoming fully himself or herself. It was St Irenaeus of Lyon who asserted that the glory of God is a human being fully alive.

Father Lapsley (2013:203) came to the conclusion that although cultural differences do exist and that these cannot be ignored, we all stay human beings, no matter where we live in the world. People all around the globe know when they are treated with dignity, love and respect, as ought to be the case with all of God's children. This is also the reason why he refers to this phase in the faith journey as that of a 'more mature healing faith' (Lapsley 2013:xi).

\section{Conclusion}

The purpose of this article was to explore whether one can speak of 'compassionate leadership', and if it is possible to identify this kind of leadership in the life and work of Father Michael Lapsley. Different heuristic devices on leadership and compassion were used in this investigation. After having a closer look at his role as a facilitator in conducting Healing of Memories workshops, his style of leadership was summarised by using four ' $c$ 's: 'creating space, cultivating imagination, crafting community and constructing liturgy'. All four of these activities support the conclusion that his style of leadership can be identified as 'compassionate leadership'. In the final section, an analysis of the operative God images in his life and work shows that underlying compassionate God images support his compassionate style of leadership. Both these findings can stimulate further academic discourse on leadership and open up the field of leadership studies to the important role of compassion in leading God's people.

\section{Acknowledgements Competing interests}

The author declares that he has no financial or personal relationships which may have inappropriately influenced him in writing this article.

\section{References}

Babbie, E. \& Mouton, J., 2001, The practice of social science research, Wadsworth, Belmont, CA.

Banks, R.J. \& Ledbetter, B.M., 2004, Reviewing leadership: A Christian evaluation of current approaches, Baker Academic, Grand Rapids, MI.

Bollnow, O.F., 2011, Human space, Translated by Christine Shuttleworth, Edited by Joseph Kohlmaier, Hyphen Press, London.

Father Michael Lapsley, 2012, viewed 12 March 2015, from https://www.aur.edu/wpcontent/uploads/2012/04/csmri-father-lapsley.jpg

Ganzevoort, R.R., 2013, Spelen met heilig vuur: Waarom de theologie haar claim op de waarheid moet opgeven, Ten Have, Rotterdam. 
George, B., 2003, Authentic leadership: Rediscovering the secrets to creating lasting value, Wiley, Hoboken, NJ.

Haslam, S.A., Reicher, S. \& Platow, M., 2011, The new psychology of leadership, Psychology Press, New York.

Institute for Healing of Memories, viewed 12 February 2015, from http://www. healingofmemories.co.za

Johnson, S.E., 1987, After a child dies: Counseling bereaved families, Churchill Livingstone, London.

Lapsley, M. \& Karakashian, S., 2013, Redeeming the past: My journey from freedom fighter to healer, Struik Publishers, Cape Town.

Louw, D.J., 2008, Cura Vitae. Illness and the healing of life, Lux Verbi. BM, Wellington.

Meyer, O., 2000, Die heelheid van gebrokenheid: 'n Nuwe styl van kerk- en Christenwees, Lux Verbi, BM, Wellington.

Nell, I.A., 2011, 'Practical theology as "healing of memories": Critical reflections on a specific methodology', HTS Teologiese Studies/Theological Studies 67(2), Art. \#1001.

Nouwen, H.J.M., 1972, The wounded healer: Ministry in contemporary society, Doubleday, New York.
Parkyn, D.L., 1995, 'Compassion', in D.J. Atkinson \& D.H. Field (eds.), New dictionary of Christian ethics and pastoral theology, pp. 244-253, Inter-Varsity Press, Leicester, England.

Restitution Foundation, viewed 15 March 2015, from http://www.restitution.org.za/

Thesnaar, C.H., 2010, 'The pastoral church as a space for healing and reconciliation' Dutch Reformed Theological Journal= Nederduitse Gereformeerde Teologiese Tydskrif 51(3 \& 4), 266-273.

Van der Ven, J.A., Dreyer, J.S. \& Pieterse, H.J., 2003, 'There is no longer Jew or Greek slave or free, male or female: Empirical Research on the Church and HIV/AIDS in South Africa' in P.D. Couture \& B.J. Miller-Mclemore (eds.), Poverty, Suffering and HIV-AIDS. International Practical Theological Perspectives, pp. 55-66, Cardiff Academic Press, Cardiff.

Vernikof, S., 2013, Father Michael Lapsley shares his tory, viewed 12 March 2015, from https://anewyorkerspointofview.com/2014/03/04/father-michael-lapsleyshares-his-story

Waghid, Y., 2004, 'Compassion, citizenship and education in South Africa: An opportunity for transformation?', International Review of Education 50(5-6), 525-542. 